\title{
Isolation and Characterization of Three Distinct Forms of Lipases from Candida rugosa Produced in Solid State Fermentation
}

\author{
Sailas Benjamin and Ashok Pandey ${ }^{*}$ \\ Biotechnology Division, Regional Research Laboratory, Council of Scientific \& Industrial Research, Trivandrum- \\ 695019, India
}

\begin{abstract}
Three distinct forms (Lip A, Lip B and Lip C) of extra-cellular lipases (EC-3.1.1.3), produced by Candida rugosa in solid state fermentation (SSF) were purified and characterised. SSF was carried out in glass columns using coconut oil cake and wheat bran. The enzyme was purified from the aqueous extract of fermented matter by ammonium sulphate precipitation, dialysis, ultra-filtration and gel filtration using Sephadex-200 to a 43-fold purification and 64.35- $\mathrm{mg} / \mathrm{ml}$ specific activity. SDS-PAGE of purified enzyme revealed three distinct bands, indicating the existence of three iso-forms, Lip A, Lip B and Lip C with apparent molecular weight about 64,000, 62,000 and 60,000 Da, respectively. All the three iso-forms were optimally active at $35-40^{\circ} \mathrm{C}$ and $\mathrm{pH}$ 7-8. They showed marked differences in their Km values with different saturated and unsaturated triacyl glycerols. Ag++ and Hg++ strongly inhibited enzyme activity of all the iso-forms, $\mathrm{Mn++}$ has no effect and $\mathrm{Ca++}$ and $\mathrm{Mg}++$ enhanced the activity. EDTA also strongly inhibited the enzyme activities of iso-forms. However, activities of all the three lipases were completely inhibited by serine protease inhibitors such as 3,4-dichloroisocoumarin, pefabloc and partially by phenylmethanesulphonyl fluoride. To the best of our knowledge, this is the first report describing the purification and characterisation of $\mathrm{C}$. rugosa lipase iso-forms from solid cultures. These lipase iso-forms with diverse characteristics produced in solid cultures may find potential application in biomedical field.
\end{abstract}

Key words: Candida rugosa, lipases, solid cultures, purification, characterization

\section{INTRODUCTION}

Lipases (EC- 3.1.1.3) possess the unique feature to act at an interface between aqueous and nonaqueous (i.e. organic) phase and this feature distinguishes them from esterases. Because of their excellent capabilities for specific regio-selective reactions in a variety of organic solvents with broad substrate recognition, lipases have emerged as an important biocatalyst in biomedical applications (Pandey et al. 1999, Benjamin and Pandey 1998a). Lipases have been used as biocatalyst for the synthesis of chiral compounds, which offer tremendous potential in the production of compounds of pharmaceutical interest (Parmar et al. 1996). Lipases have been employed for hydrolysing racemic esters (trans-esterification and racemization in situ) to produce optically pure enantiomeric compounds, which are used in the synthesis of chiral synthons (Reddy 1992, Akita et al. 1995, Lee et al. 1995). Lipases are used as biocatalyst in the synthesis of life-saving drugs (Pandey et al. 1999, Jaeger et al. 1994, Benjamin and Pandey 1996). These include synthesis of nikkomycin-B, non-steroidal anti-inflammatory drugs such as naproxen, ibuprofen, suprofen and ketoprofen, anti-viral agent lamivudine, etc. They have also been used for the synthesis of anti-tumor drugs, alkaloids, antibiotics, etc. [Pandey et al. 1999, Yokomatsu et al. 1995, Fernandez et al. 1995, Yoshinan et al. 1994, Itoh et al. 1993).

Application of lipases for biomedical application and in pharmaceutical industries require them in high-purity grade with known specific properties, which include properties with respect to substrate and processing parameters such as $\mathrm{pH}$, temperature etc. Therefore, it is essential to characterise lipase obtained from a particular

\footnotetext{
Author for correspondence
} 
source to determine its potential for biomedical applications.

Occurrence of iso-lipases has been a common feature in many yeasts such as Geotrichum candidum, C. antartica, C. rugosa, moulds such as Aspergillus niger, A. oryzae, Penicillium cyclopium, Rhizopus miehei, and bacteria such as Chromobacterium viscosum (Benjamin and Pandey 1998a). C. rugosa lipases have been termed of great significance for their diverse biotechnological potential (Pandey et al. 1999). Existence of $C$. rugosa lipase iso-forms has been reported by several authors [Pandey et al. 1999, Benjamin and Pandey 1998a, Jaeger et al. 1994). We used a strain of $C$. rugosa for extra-cellular lipase production in submerged fermentation $(\mathrm{SmF})$ and solid state fermentation (SSF) (Benjamin and Pandey 1996, 1997a, b, 1998b). Interestingly, the enzyme titres in SSF were manyfolds higher. We made an attempt to purify and characterise the enzyme produced by $C$. rugosa in SSF for its possible application in biomedical and pharmaceutical sectors..

\section{MATERIALS AND METHODS}

Micro-organism, inoculum and fermentation: A yeast strain of Candida rugosa (DSM-2031) was used. Its growth and maintenance conditions and inoculum preparation were same as described elsewhere (Benjamin and Pandey 1996). SSF was carried out in a column fermenter at $28^{\circ} \mathrm{C}$ with aeration using a mixed substrate containing coconut oil cake (COC) and wheat bran (WB) in 1:2 dry weight ratio as described previously (Benjamin and Pandey 1997b).

Extraction of Crude Protein from the Fermented Matter: Fermented matter (72 h old) was homogenised manually and a portion $(5 \mathrm{~g})$ was extracted with $20 \mathrm{ml}$-distilled water on a magnetic stirrer for $15 \mathrm{~min}$. The extract was centrifuged at $5000 \mathrm{rpm}$ for $10 \mathrm{~min}$ at $4^{\circ} \mathrm{C}$ to get a debris-free supernatant. This preparation was termed as crude extract (Fraction I).

Fractionation with ammonium sulphate, dialysis and ultrafiltration: Solid ammonium sulphate was added to the Fraction I at 20\% saturation and allowed to stand for $30 \mathrm{~min}$. The precipitate so obtained was separated by centrifugation ((Fraction II) and the resulting supernatant was further treated with solid ammonium sulphate at $40 \%$ saturation. The precipitate so obtained was collected by centrifugation (Fraction III). The supernatant was similarly treated with ammonium sulphate at 60 , 80 and $100 \%$ saturation and the precipitates obtained were termed as Fractions IV, V, respectively. All the precipitates (II-V) were resuspended in a minimal amount of buffer $(0.1 \mathrm{M}$ Tris- $\mathrm{HCl}, \mathrm{pH}$ 7.0) and dialysed against the same buffer by using successive large volumes of buffer. The process was continued till the last traces of ammonium sulphate were removed. The desalted fractions were subjected to concentration by ultra-filtration with a cut off range of $10 \mathrm{kDa}$ (Millipore, USA). Subsequently, all the concentrated fractions (II-V) were subjected to protein and lipase assay to choose the fraction containing maximum lipase activity. Lipase activity is expressed as $\mathrm{U} / \mathrm{ml}$ and one unit (U) of lipase activity is defined as $\mu$ mols of free fatty acids liberated $/ \mathrm{min} / \mathrm{ml}$ by the enzyme solution, under the assay conditions (Benjamin and Pandey 1997b).

Analytical methods: Protein and lipase assays were performed by the methods of Lowry et al. (1951) and Safarik (1991), respectively. Lipase assay conditions were similar as described previously (Benjamin and Pandey 1997b).

Sephadex G-200 gel filtration chromatography: Fraction IV was applied onto a column (30x1.5 $\mathrm{cm})$ packed with Sephadex G200 (Sigma, USA), which was previously equilibrated with $0.1 \mathrm{M}$ Tris$\mathrm{HCl}(\mathrm{pH} 7.0)$. The column was eluted with the same buffer with a flow rate of $30 \mathrm{ml} / \mathrm{h}$ using a peristaltic pump. Samples $(3 \mathrm{ml})$ were collected using a fraction collector and each fraction was assayed for lipase activity.

SDS-PAGE: The fractions (53-66) showing lipase activity were pooled together and subjected to the sodium dodecyl sulphate-polyacrylamide gel electrophoresis (SDS-PAGE) and also for polyacrylamide gel electrophoresis (PAGE) under non-denaturing conditions. In another set of experiments, lipase active fractions corresponding to the specific peaks (three peaks, obtained during the activity studies of pooled lipase active fractions) were separately collected (according to the peaks) for loading on the PAGE after 
concentration by ultra-filtration.

For electrophoresis in the presence of SDS (native PAGE), samples and control were boiled for $3 \mathrm{~min}$ in the sample buffer, which contained 5\% 2mercapto ethanol and $1 \%$ bromophenol blue. Coomassie brilliant blue was used to stain the protein band Laemmli (1970). Electrophoresis in the absence of SDS (native PAGE) was carried out on $8 \%$ polyacrylamide gels in Tris-glycine buffer (pH 8.8) (Bollag and Edelstein 1992). Electrophoresis was performed on a vertical slab mini-gel apparatus (Biotech, India) at $100 \mathrm{~V}$ for 5$6 \mathrm{~h}$. Active lipase bands were detected in the nondenaturing gel after its extraction from the untreated gel slices. The gel slices were homogenised and kept in $0.1 \mathrm{M}$ Tris- $\mathrm{HCl}$ buffer $(\mathrm{pH}$ 7.0) for $1 \mathrm{~h}$ for passive diffusion of the lipase proteins into the buffer. Lipase-containing extract was obtained by eliminating the gel derbies by centrifugation in an Eppendorf Centrifuge (3000 rpm for $10 \mathrm{~min}$ ). Molecular weight markers contained myosin (205 kDa), B-galactosidase (116 kDa), Phosphorylase-B (97 kDa), Bovine Serum Albumin (66 kDa) and Ovalbumin (45 kDa) (Sigma, USA). Fractions separated as above were used for further studies and the characterisation of lipase iso-enzymes.

Characterisation of lipase iso-enzymes: In order to distinguish distinct characteristics of isolated iso-enzymes, substrate specificity, thermosensitivity, $\mathrm{pH}$ tolerance and effect of ions and inhibitors on their activity were investigated.

Fatty acid specificity: The enzyme fractions were incubated with the triglycerides such as triolein, tripalmitin, trilaurin, tricaprin and tributyrin at a final concentration of $20 \mathrm{mM}$, which was used as the standard to compare the resultant values. The reaction mixture contained the usual ingredients used for lipase assay in $0.1 \mathrm{M}$ Tris- $\mathrm{HCl}$ buffer $(\mathrm{pH}$ 7.0) at $37^{\circ} \mathrm{C}$. Sequential dilutions of the substrates were done to determine $\mathrm{Km}$ values.

Thermostability: To investigate lipase stability, the enzyme mixtures were pre-incubated at various temperature (25-65 at $\mathrm{pH} 7.0$ ) in Tris- $\mathrm{HCl}$ buffer, before lipase assay. Incubation persisted for 0-300 min under the assay conditions, and the results are reported as relative activity (\%). The samples were withdrawn after 5-30 min intervals, and the results are shown as 30 min intervals.

pH tolerance: To investigate $\mathrm{pH}$ tolerance, enzyme mixtures were pre-incubated at different $\mathrm{pH}$ values $\left(5.5-9.5\right.$ at $\left.37^{\circ} \mathrm{C}\right)$ for $30 \mathrm{~min}$ in the assay mixture as described above.

Effect of Metal Ions and Inhibitors: Lipase fractions were pre-incubated for $1 \mathrm{~h}$ at $37^{\circ} \mathrm{C}(\mathrm{pH}$ 7.0 ) and in $0.1 \mathrm{M}$ Tris- $\mathrm{HCl}$ buffer with various ions or chelating compounds/other chemicals (one at a time) at various concentrations $\left(10^{-2}\right.$ to $\left.10^{-4} \mathrm{M}\right)$. Assay was performed with the mixture, which did not contain $\mathrm{CaCl}_{2}$ (except in test sample). The ions used included $\mathrm{Hg}, \mathrm{Cu}, \mathrm{Co}, \mathrm{Ag}, \mathrm{Ca}, \mathrm{As}, \mathrm{Na}, \mathrm{K}$, $\mathrm{Zn}, \mathrm{Mn}, \mathrm{Mg}$ and Fe. Chelating agents and other chemicals tested were ethylene diamine tetra acetic acid (EDTA), the anionic detergent, sodium dodecyl sulphate (SDS), thiol-binding parachloromercuric benzoate (PCMB), and serine protease inhibitors such as phenyl methane sulphonyl fluoride (PMSF), 3,4dichloroisocoumarin (3-4,DCI) and pefabloc.

\section{RESULTS AND DISCUSSION}

Purification and Isolation of Lipases: A representative purification profile of the lipase active fractions is summarised in Table 1. $C$. rugosa lipases (CRL) were purified to about 43fold with $22.5 \%$ activity recovery. From the elution profile of proteins, which is shown in Fig.1, lipase active fractions were represented by the fractions between 53 and 66. When these fractions were pooled together and subjected to activity studies, three distinct peaks were obtained, which for convenience, designated as peaks $\mathrm{a}, \mathrm{b}$ and $\mathrm{c}$ in succession (Fig.2). These peaks clearly indicated that the above fractions contained different lipase iso-forms with varying activity characteristics. These findings were further confirmed by the results obtained by SDS-PAGE electrophoresis (Fig.3), and also the characterisation studies. 


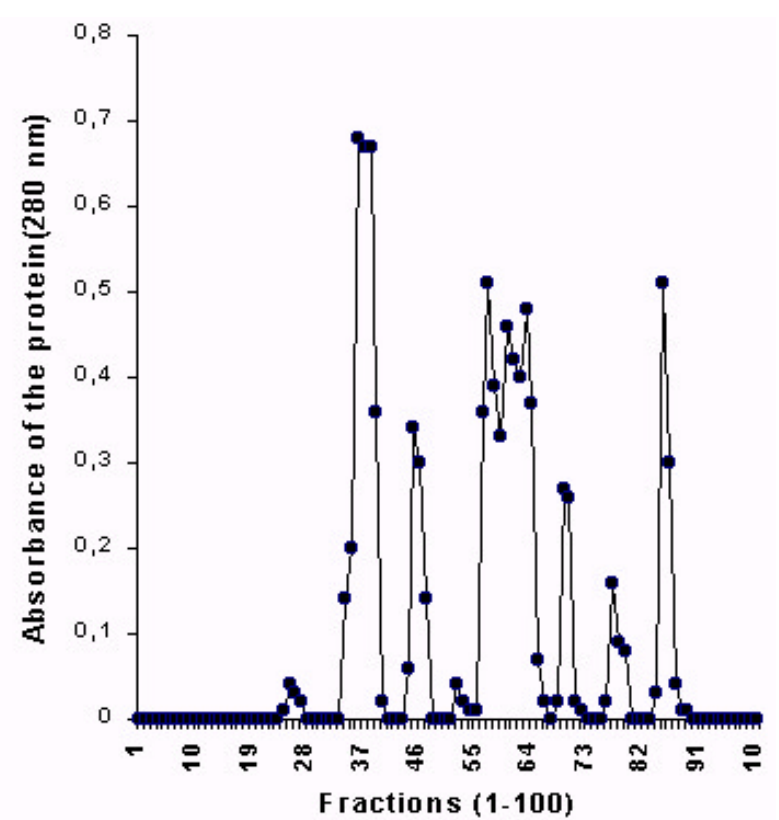

Figure 1 - Elution profile of lipases from Sephadex G 200 column. A: absorbance at $280 \mathrm{~nm}$ and B: lipase activity $\left(\mathrm{Uml}^{-1}\right)$.
In Fig.3, pattern on lane D clearly showed three distinct bands contained in the pooled lipase active fractions (corresponding to Sephadex G-200 elutes, fractions between 53 and 66). Bands in lanes E (peak-a), F (peak-b) and $\mathrm{G}$ (peak-c) represented 3 distinct forms of $C$. rugosa lipases, which were the representatives of the peaks in order of their elution from the column (Fig.2). To get these individual bands, fractions corresponding to each peak were separately pooled and loaded on lanes $\mathrm{E}, \mathrm{F}$ and $\mathrm{G}$, respectively. The bands on lanes $\mathrm{E}, \mathrm{F}$ and $\mathrm{G}$

Table 1 - Purification of Candida rugosa extra-cellular lipases.

\begin{tabular}{|c|c|c|c|c|c|}
\hline Purification & $\begin{array}{l}\text { Total protein } \\
(\mathrm{mg} / \mathrm{ml})\end{array}$ & $\begin{array}{l}\text { Specific } \\
\text { activity } \\
(\mathrm{U} / \mathrm{mg})\end{array}$ & $\begin{array}{l}\text { Total } \\
\text { activity } \\
\text { (U/ml) }\end{array}$ & $\begin{array}{l}\text { Activity } \\
\text { recovery }(\%)\end{array}$ & Purificat-ion(fold) \\
\hline Culture supernatant & 32.77 & 1.48 & 48.61 & 100 & 1 \\
\hline $\begin{array}{l}\left(\mathrm{NH}_{4}\right)_{2} \mathrm{SO}_{4} \quad(40-60 \%) \\
\text { saturation supernatant }\end{array}$ & 4.68 & 3.88 & 18.14 & 37.32 & 2.62 \\
\hline Sephadex G-200 & 0.46 & 28.96 & 13.32 & 27.40 & 19.56 \\
\hline PAGE(native) fraction & 0.17 & 64.35 & 10.94 & 22.51 & 43.48 \\
\hline Lip A & 0.060 & 75.89 & 4.25 & 11.62 & 51.27 \\
\hline Lip B & 0.021 & 26.67 & 0.56 & 1.15 & 18.02 \\
\hline Lip C & 0.018 & 97.22 & 1.75 & 3.64 & 65.69 \\
\hline
\end{tabular}


Table 2 - Effect of different metal ions on lipase activity. The results are expressed in relative activity.

\begin{tabular}{|c|c|c|c|c|}
\hline \multirow{2}{*}{ Metal ions } & \multirow{2}{*}{$\begin{array}{l}\text { Final Molar } \\
\text { Concentration }\end{array}$} & \multicolumn{3}{|c|}{ Relative activity (\%) } \\
\hline & & $\underline{\operatorname{Lip} A}$ & $\underline{\text { Lip B }}$ & $\underline{\operatorname{Lip} C}$ \\
\hline Control & Nil & 100 & 100 & 100 \\
\hline $\mathrm{AgCl}_{2}$ & $10^{-4} \mathrm{M}$ & 57 & 50 & 48 \\
\hline $\mathrm{AsCl}_{2}$ & $10^{-4} \mathrm{M}$ & 73 & 71 & 76 \\
\hline $\mathrm{CaCl}_{2}$ & $10^{-2} \mathrm{M}$ & 127 & 131 & 125 \\
\hline $\mathrm{CoCl}_{2}$ & $10^{-3} \mathrm{M}$ & 85 & 84 & 81 \\
\hline $\mathrm{CuCl}_{2}$ & $10^{-3} \mathrm{M}$ & 83 & 80 & 81 \\
\hline $\mathrm{FeSO}_{4}$ & $10^{-3} \mathrm{M}$ & 87 & 75 & 77 \\
\hline $\mathrm{HgCl}_{2}$ & $10^{-4} \mathrm{M}$ & 46 & 54 & 49 \\
\hline $\mathrm{KCl}$ & $10^{-3} \mathrm{M}$ & 84 & 84 & 49 \\
\hline $\mathrm{MgCl}_{2}$ & $10^{-2} \mathrm{M}$ & 118 & 118 & 117 \\
\hline $\mathrm{MnCl}_{2}$ & $10^{-2} \mathrm{M}$ & 103 & 100 & 104 \\
\hline $\mathrm{NaCl}$ & $10^{-3} \mathrm{M}$ & 86 & 73 & 71 \\
\hline $\mathrm{ZnSO}_{4}$ & $10^{-3} \mathrm{M}$ & 78 & 80 & 80 \\
\hline
\end{tabular}

were named as Lip A, Lip B and Lip $C$, respectively (Figs.2 and 3). Lane E showed much clear band that could be considered as the representative of Lip A The locations of these three individual bands in the gel coincided with three bands on lane D. The apparent molecular weight (MW) of Lip A, Lip B and Lip C were about 64,000, 62,000 and 60,000 Da, which suggested that none of these was a proteolytic product of the other. This view was further supported by the characterisation studies (Figs.4 9). In fact, such slight variations could be attributed to the partial purity and also difference in amounts of glycosylation in the lipase proteins. Apparent MW of Lip $C(60 \mathrm{kDa})$ was in concordance with the observations of Lotti et al. (1994). It could be purified to 66-fold (maximum purity obtained in the present investigations), with about $97 \mathrm{U} / \mathrm{mg}$ specific activity (Table 1). Purification fold of Lip B was relatively very low, i.e. only 18 -fold with minimum specific activity, i.e. about $27 \mathrm{U} / \mathrm{mg}$. Lip A was purified about 51fold purification with about $76 \mathrm{U} / \mathrm{mg}$ specific activity. Activity recovery was maximum (11.62\%) for Lip A, which was 10 -fold more than Lip $B$ and 3.2-old more than Lip $C$ (Table 1). Hence, it could be concluded that Lip A was the major component in the enzyme mixture.

\section{Characterisation Studies}

Substrate Specificity: Figure 4 shows the profile of different substrate specificity of the three isoforms. Lip A showed preference for short chain saturated triglycerides as indicated by its affinity
$(\mathrm{Km}=0.4 \mathrm{mM})$ for tributyrin, 4:0, and also decreasing affinity with increasing chain length. In fact, it showed same preference for both saturated (tripalmitin, C18: 0) and unsaturated (triolein, 18:1n-9) fatty acids with same chain length. Lip B showed strong discrimination towards unsaturated triglyceride (triolein), but its kinetic behaviour showed that it has preference for medium chain triacyl glycerols. Lip $C$ also showed strong affinity towards medium chain saturated triglyceride. These results, in general, revealed that CRL isoforms preferred short chain or medium chain saturated fatty acids for their hydrolysis from the glycerol moiety. Langrand et al. (1990) also reported that CRL was effective for synthesising short chain flavour esters, which have commercial potential.

As far the physiological relevance of lipase isoforms for the producing organism is concerned, one could speculate that the availability of related but non-identical enzymes would improve its adaptation to different nutrient habitats, i.e. creating different ecological niches for better survival. This view gets support from the recent description on lipase iso-enzymes of G. candidum, a close relative of $C$. rugosa with different substrate specificity by Bertolini et al. (1995). Two distinct lipases of $C$. rugosa characterised by Rua and Ballesteros (1994) were also in concordance to this view. However, it should be kept in mind that the difference in activity might be related to the number of enzyme molecules present in the sample, because as mentioned earlier, the number of Lip A molecules must be 
more than the other two iso-forms, i.e. Lip B and Lip $C$ under the same assay conditions.

Effect of temperature: In general, all the three isoforms manifested that prolonged incubation would adversely affect their activity (Figs.5-7). Lip B, however, showed relatively better tolerance for higher temperatures $\left(45-50^{\circ} \mathrm{C}\right)$ for $2 \mathrm{~h}$ without much loss in activity (Fig.6). Lip A and Lip C showed best tolerance at $35-45^{\circ} \mathrm{C}$ range (Figs.5 and 7 , respectively). During the first $30 \mathrm{~min}$ of incubation at $60^{\circ} \mathrm{C}$, over $85 \%$ of the activity of $\mathrm{Lip}$ $A$ was lost, however, it showed better thermotolerance than Lip B and Lip C. All the iso-forms showed optimum activity at $35-40^{\circ} \mathrm{C}$ for an incubation period of $30 \mathrm{~min}$ (maximum relative activity about $90 \%$ ).

The basis for stability at relatively higher temperatures is still unclear, but it might be linked to the fact that the lipases are highly hydrophobic (Gordillo et al. 1995). The hydrophobic amino acids should be concentrated near the catalytic centre. Such amino-acids found on the side of the 'lid' that overarching the catalytic site (Ser-His-Glu triad) become completely exposed, with greatly expanding the non-polar surface around the active site and may explain the stability of lipase at relatively high temperatures (Benjamin and Pandey 1998a, Lotti et al. 1994, Grochulksi et al. 1993).

Effect of $\boldsymbol{p H}$ : A comparison of activity profile of all the lipase iso-forms is shown in Fig.8. Lip A was found to be highly sensitive to $\mathrm{pH}$ change and preferred neutral $\mathrm{pH}$ (7.0) as the optimum; Lip B and Lip $C$ showed best activity at slightly alkaline pH. Lip $B$ was optimally active at $\mathrm{pH} 7.5-8.0$ and Lip $C$ at $\mathrm{pH}$ 7.0-7.5. In general, none of these showed preference for acidic $\mathrm{pH}$. Exact mechanism behind $\mathrm{pH}$ sensitivity is also not clear. However, the stability studies of C. rugosa lipase conducted by Hernaiz et al. (1994) focussed mainly on the conformational changes in relation to the topology of lipase protein, caused by $\mathrm{pH}$ changes. That changes might reduce or impose strain on the 'lid' overarching the active centre, thereby open or shut down the catalytic centre for substrate binding (Benjamin and Pandey 1998a).

Effect of metal ions, chelators and other chemicals: Table 2 shows the results on the effect of various metal ions on the activity of the lipase iso-forms. Except Mn++, which showed no effect of enzyme activity and $\mathrm{Ca}++$ and $\mathrm{Mg}++$, which highly favoured the activity at $10^{-2} \mathrm{M}$ concentrations, all other ions tested in the present study showed inhibition with relative degree of variation. Evidently even at $10^{-4} \mathrm{M}$ concentrations, $\mathrm{Ag}++$ and $\mathrm{Hg}++$ highly retarded the activity of all the lipase iso-forms. Inhibitory role of As++ was also pronounced.

Effect of different chelators and other chemicals is presented in Fig.9. Activities of all the three lipases were completely inhibited by the protease inhibitors such as 3,4-DCI and pefabloc. PMSF, another serine protease inhibitor, however, retained the activity by about $25 \%$. Influence of thiol-binding reagent, the PCMB showed only $25 \%$ inhibition. The ion chelator, EDTA and anionic detergent, SDS, retarded about $75 \%$ of activity. Inhibitory action of the former was stronger than that of the latter. Action of these two compounds could be attributed to their effect in creating the imbalance of ions in the reaction mixture by absorption or release, respectively.

Purified iso-lipases from C. rugosa have been used for different biomedical and pharmaceutical purposes. Hernaiz et al. (1994) isolated two forms of iso-lipases (A and B) form C. rugosa which were used for esterification reaction to produce ibuprofen. Both of these forms were different in characteristics. It has also been shown that origin of different iso-forms obtained from different sources has impact on performance of different reactions (e.g. esterification in dry homogenous organic media to produce compounds of pharmaceutical importance) as they possessed different characteristics to different degrees. Secretion of all the lipase iso-forms may not be equitable, and the environment in which it grows would influence the extent of the secretion of a particular iso-form. C. rugosa iso-lipases as produced in non-conventional solid medium (present studies) needs attention, as it could offer potential advantages for production of compounds of pharmaceutical importance.

\section{RESUMO}

Três formas distintas (Lip A, Lip B e Lip C) de lipases extracelulares (EC- 3,1,1,3), produzidas por Candida rugosa em fermentação no estado sólido (SSF) foram purificadas e caracterizadas. A fermentação foi realizada em colunas de vidro 
usando como substrato bolo de óleo de coco e o farelo de trigo. O enzima obtida no extrato aquoso do material fermentado foi precipitada com do sulfato de do amônio, dialisada, ultra-filtrada e filtrada em gel usando Sephadex-200 obtendo assim um nível de purificação de 43-fold e uma atividade específica de $64,35 \mathrm{mg} / \mathrm{ml}$. SDS-page da enzima purificada revelou três bandas distintas, indicando a existência de três iso-formas distintas, a banda $\mathrm{A}$, a banda $\mathrm{B}$ e a banda $\mathrm{C}$ com pesos moleculares aparentes de 64.000, 62.000 e 60.000 $\mathrm{Da}$, respectivamente. Todas as três iso-formas foram oticamente ativas entre $35-40^{\circ} \mathrm{C}$ e a $\mathrm{pH}$ 7-8. Mostraram diferenças marcantes em seus valores do $\mathrm{Km}$ com triacyl glycerols saturado e não saturado. A atividade das enzimas de todas as três iso-formas foi fortemente inibida pelo $\mathrm{Ag}++\mathrm{e}$ $\mathrm{Hg}++$. O Mn++ não apresentou nenhum efeito e o $\mathrm{Ca}++\mathrm{e} \mathrm{Mg}++$ realçaram a atividade das enzimas. O EDTA também inibiu fortemente a atividades das iso-formas da enzima . Entretanto, as atividades de todos as três lipases foram inibidas completamente por inibidores da serina protease como 3,4-dichloroisocoumarin, por pefabloc e parcialmente pelo fluoreto de phenylmethanesulphonyl. Segundo nossos conhecimentos, este é o primeiro estudo que descreve a purificação e a caracterização de isoformas de lipases da C. rugosa em cultura sólida. Essas iso-formas de lipases com as características diversas produzidas em culturas sólida podem encontrar a aplicações em potencial no campo da biomedicina.

\section{REFERENCES}

Akita, H., Chen, C. Y. and Ucheda, K. A. (1995) Tetrahedr. Asymm., 6, 2131-2134

Benjamin, S. and Pandey, Ashok (1996a) Candida rugosa and its lipases - A retrospect, J. Sci. Ind. Res., 57, 1-9

Benjamin, S. and Pandey, Ashok (1996b) Optimi-zation of liquid media for lipase production by Candida rugosa, Biores. Technol., 55, 167-170

Benjamin, S. and Pandey, Ashok (1997a) Enhancement of lipase production during repeated batch cultivation using immobilised Candida rugosa, Process Biochem., 32, 437-440

Benjamin, S. and Pandey, Ashok (1997b) Coconut cake - a potent substrate for the production of lipase by Candida rugosa in solid state fermentation. Acta Biotechnol., 17, 241-251
Benjamin, S. and Pandey, Ashok (1998a), Candida rugosa lipases: Molecular biology and versatility in biotechnology, Yeast, 14, 1069-1087

Benjamin, S. and Pandey, Ashok (1998b) Mixed solidstate fermentation- a novel process for the enhanced production of lipase by Candida rugosa. Acta Biotechnol., 18, 315-324

Bertolini, M.C., Schrag, J.D., Cygler, M., Thomas, D.Y. and Vernet, T. (1995) Expression in yeast, characterisation and comparison of lipases from Geotrichum candidum. Yeast, 11 Spc.Iss. S523.

Bollag, D.M. and Edelstein, S.J. (1992) Gel Electrophoresis under non-denaturing conditions. InProtein Methods, pp.145-159 Wiley-Liss, New York

Fernandex, S., Ferreros, M., Gotor, V. and Okamura, W. H. (1995), Org. Chem., 60, 6057-6061

Gordillo, M.A., Obradors, N., Montesinos, J.L., Valero, F., Lafuente, J. and Sola, C. (1995) Stability studies and effect of initial oleic acid concentration on lipase production by Candida rugosa. Appl. Microbiol. Biotechnol., 43, 38-41.

Grochulski, P., Li, Y., Schrag, J.D., Bouthiller, F., Smith, P., Harrison, D., Rubin, B. and Cygler, M. (1993) Insights into interfacial activation from an open structure of Candida rugosa lipase. J. Biol. Chem., 268, 12843-12847

Hernaiz, M.J., Rua, M., Celda, B. and Medina, J.M. (1994) Contribution to the study of the alternation of lipase activity of Candida rugosa by ions and buffers. Appl. Biochem. Biotechnol., 44, 213-229.

Jaeger, K.E., Ransak, S., Djkstra, B.W., van Henrel, C.C. and Misset, O. (1994) FEMS Microbiol. Rev., 15, 29-63

Itoh, T., Ohika, J., Takagi, Y. and Nishiyama, S. (1993) Org. Chem., 58, 5717-5723

Laemmli, U.K. (1970) Cleavage of structural proteins during the assembly of bacteriophage $\mathrm{T}_{4}$. Nature, 227, 680-685.

Langrand, G., Randot, N., Triantaphilides, C. and Baratti, C. (1990), Short chain flavour esters synthesis by microbial lipases. Biotechnol. Lett., 12, 581-586.

Lee, W. H., Kim, K. J., Kim, M. G. and Lee, S. B. (1995) J. Ferment. Bioeng., 80, 613-615

Lotti, M., Tramontano, A., Longhi, S., Fusetti, F., Brocca, S., Pizzi, E. and Alberghina, L.(1994) Variability within the Candida rugosa lipases family, Protein Eng., 7, 531-535

Lowry, O.H., Rosebrough, N.J., Farr, A.L. and Randall, R. J. (1951), Protein measurement with the folinphenol reagent, J. Biol. Chem., 193, 265-275.

Pandey, Ashok, Benjamin, S., Soccol, C.R., Nigam, P., Krieger, N. and Soccol, V.T. (1999) The realm of lipases in biotechnology, Biotechnol. Appl. Biochem., 29, 119-131

Parmar, V. S., Bisht, K. S. Singh, A. and Jha, A. (1996) Proc. Indian Acad. Sci., 108, 575-583 
Reddy, D. R. (1992), In- Industrial Biotechnology (Malik, V. S. and Sridhar, P., eds.), pp. 387-404, Oxford \& IBH Publishing Co., New Delhi.

Rua, M.L. and Ballesteros, A. (1994), Rapid purification of two lipase isoenzymes from Candida rugosa, Biotechnol. Tech., 8, 21-26

Safarik, I. (1991) A spectrophotometric assay for lipase activity utilizing triacyl glycerols, J. Biochem. Biophys. Methods, 23, 249-253.
Yokomatsu, T., Nakabayashi, N., Matsumoto, K. and Shibuya, S. (1995), Tetrahedr. Asymm., 6, 3055-3062 Yoshinan, K., Aoki, M., Ontsuka, T., Nakayama, N., Itezono, Y., Mutoh, M., Watanbe, J. and Yokuse, K. (1994), Antibiotics, 47, 1376-1384

Received: January 05, 2000; Revised: April 07, 2000; Accepted: June 07, 2000. 